\title{
THE INFLUENCE OF SHOPPING MALLS ON YOUTH LIFESTYLE
}

\author{
Yohannes Firzal $^{\left.a^{*}\right)}$, Kartika Syahrani ${ }^{b)}$ \\ ${ }^{a)}$ Universitas Riau, Pekanbaru, Indonesia \\ ${ }^{b)}$ BAPPEDALITBANG Riau, Pekanbaru, Indonesia \\ ${ }^{*}$ Corresponding Author: yfirzal@eng.unri.ac.id
}

Article history: received 09 January 2021; revised 13 January 2021; accepted 26 January 2021

\begin{abstract}
Shopping malls can influence adolescents' lifestyle. Adolescents' ability to adjust lifestyle has assumed dynamism in the social order system and a symbol of identity. In this context, the relationship between adolescent lifestyles and shopping malls is interesting to investigate how the dimensions of youth lifestyle influence and shopping mall attractiveness indicators identify adolescent visitors' characteristics. By using the incidental sampling technique, this quantitative research data involved 97 adolescents as respondents through interview and questionnaire methods, secondary data support, and multiple regression methods consisting of 5 independent variables, namely convenience, comfort, diversity, entertainment, luxury and essence of the mall and one lifestyle dependent variable. Two data analysis techniques; cross-table analysis of respondent characters and statistical analysis using SPSS software to support study in the Linkert Scale, followed by validity testing, reliability testing, classical assumption test, multiple regression test, $\mathrm{t}$-test (partial), $\mathrm{F}$ test (simultaneous) and coefficient determination. The analysis found that the comfort variable is the most significant variable that impacts adolescent lifestyle. Therefore, there needs to be intensive supervision of mall activities with a high level of convenience to anticipate deviant actions that are feared to harm teenage lifestyles
\end{abstract}

Keywords: adolescents; youth; lifestyle; shopping mall

\section{INTRODUCTION}

The existence of shopping malls affects teenagers [1]. Not only related to searching social identity; on one side, adolescents tend to judge themselves as modern when they are often in and out of the mall. On another side, adolescents also assume a mall is a place of recreation and lifestyle. Furthermore, shopping malls are used as a place for selfactualization, influencing behaviour, psychology, and appearance to shape adolescent lifestyles [2].

As part of secondary needs, the human lifestyle can influence by time or the desire to change [3]. An ability in adjusting lifestyle seems like an indicator of a dynamic individual who is up to date or a conventional individual who has attached to a particular social order. More profoundly, this assumption can also be found as a symbol of prestige in the social order system, such as the use of fashionable items in everyday life, ways of behaving (ethics), habits (habitus), and frequently visited places and the language used. Not only to communicate solely but also for the symbol of identity [4]. In looking for self-identity, adolescents tend to have the ability to adjust their lifestyle more dynamically through various things, including the intensity of visiting shopping malls.

In this context, the research with the theme of the relationship between adolescent lifestyles and shopping malls becomes interesting regarding the extent to which the influence of youth lifestyle dimensions (shopping, community, food, entertainment, education) and shopping mall attractiveness indicators (completeness, comfort, diversity, enjoyment and integrity). Research with a similar theme to this research has conducted many perspectives, such as how the lifestyle of adolescents is carried away by a consumptive culture with the emergence of shopping malls [1] where shopping malls have the potential to change behaviour [2] and have an influence on visitors [5]. The phenomenon of impact on adolescents has also influenced by the increasing number of food and beverage facilities available in shopping malls, which has become a unique attraction for teenagers [6]. Therefore, the researcher is interested in investigating the influence of shopping malls on adolescent lifestyles by identifying these teenage visitors particular problems at the Living World Mall in Pekanbaru City.

\section{RESEARCH METHODS}

This research has conducted by using a quantitative survey method. The method aims to collect data related to the past and present relating to beliefs, opinions, characteristics, behaviour, variable relationships, and initial testing of hypotheses about sociological and psychological variables. Data collection techniques have conducted by observation, interviews, questionnaires that tend to be generalizable [7].

The primary data have obtained from teenage respondents who visited the Living World Mall. The timeframe data collection is carried out on a working day (Thursday) and weekend (Sunday) within 3 hours between 03.00 - $06.00 \mathrm{PM}$ for four consecutive weeks and in a consistent time. With this timeframe, the average number of approximately 128 adolescents visited the Living World Mall. This figure has used as an estimated population figure. The estimated amount is the basis for determining the study 
population to be 97 people but still qualifying as representative of the study population [8] [9].

This primary data collection technique is through incidental sampling technique [10] using questionnaires and observations to reach the target population of respondents who have planned. The primary data has also obtained from direct interviews with the Living World Mall's operational manager. Meanwhile, secondary data have collected from various government agencies, such as population data and data on visits to tourism objects and malls.

Two analysis techniques have performed on the data, namely, cross-table analysis of the respondent's character and statistical analysis using SPSS software [10] to support further investigation in the Linkert Scale [11]. The tables generated from the data analysis will undergo several tests such as the reliability test, validity test, multiple regression test, classical assumption test, t-test (partial), F test (simultaneous) and the coefficient of determination (R2).

The researcher has used several fundamental theories, such as the theory of shopping malls' attractiveness towards adolescents related to several attributes: comfort, diversity, entertainment, luxury, and essence [6]. This study's other ideas are related to adolescent lifestyle theories measured through three indicators: activities, interests, and opinions [12].

\section{RESULTS AND DISCUSSION}

\section{The Validity test}

The validity test aims to measure the questionnaire's validity or invalidity by testing all types of questions used. It is conducting by comparing the numbers obtained from statistical data processing (r-value) and figures derived from existing statistical tables ( $r$-table). The value of $r$-count $>r-$ table is declared valid, and if the amount of r-count $<$ r-table is declared invalid. With the help of the SPSS tool to process the questionnaire data, the values of all r-count $>$ r-table were obtained, with $r$ tables $=0.198$. This test shows that the questionnaire used is valid.

\section{The Reliability Test}

Reliable (reliable) from a questionnaire if the respondents' answers to the questionnaire statements have been consistent or stable from time to time. A reliability test has carried out on data that has been declared valid. By using SPPS, reliability is calculated through Cronbach Alpha $(\alpha)$ statistical analyses with criteria 1) $\alpha$ value $>0.7$, then the variable is said to be reliable, and if 2) $\alpha$ value $<0.7$, then the variable is declared to be unreliable. Based on the questionnaire data that has been processed by SPSS Version 23 , the results are as shown in the table below (Table 1):

Table 1. The Reliability Test On The Independent And Dependent Variables

\begin{tabular}{lccc}
\hline \multicolumn{1}{c}{ Variable } & Cronbach's Alpha & Value & Remark \\
\hline Constant & 0,767 & 0,7 & Reliable \\
Convenience & 0,751 & 0,7 & Reliable \\
Comfort & 0,716 & 0,7 & Reliable \\
Diversity & 0,709 & 0,7 & Reliable \\
Entertainment & 0,781 & 0,7 & Reliable \\
Life Style & 0,730 & 0,7 & Reliable \\
\hline
\end{tabular}

\section{The Classical assumption test}

The Classical Assumption Test consists of several tests, namely 1) multicollinearity test, 2) autocorrelation test, 3) heteroscedasticity test, and 4) normality test. The Classical Assumption Test aims to determine whether there is a correlation between the independent variables (independent) in the regression model. This test is determined based on the tolerance value and VIP value. Multicollinearity occurs if the tolerance value $\leq 0.10$ and the VIP value $\geq 10$. Based on the questionnaire data processed through SPSS, the tolerance and VIP values have obtained as follows (Table 2):

Table 2. The Classic Assumption Test

\begin{tabular}{lcc}
\hline \multicolumn{1}{c}{ Model } & \multicolumn{2}{c}{ Collinearity Statistics } \\
& Tolerance & VIP \\
\hline Constant &, 454 & 2,203 \\
Convenience &, 369 & 2,712 \\
Comfort &, 264 & 2,792 \\
Diversity &, 587 & 1,703 \\
Entertainment &, 366 & 2,731 \\
\hline
\end{tabular}

From table 2, it has used to figure the tolerance value of all independent variables is $>0.10$ and the VIF value $<10$. The value indicates that there is no correlation between the independent variables. Furthermore, the auto-correlation test aims to determine whether there is a correlation between confounding error in period $\mathrm{t}$ and confounding error in period t-1 (previously) in the linear regression model; a good regression model is free from autocorrelation.

The presence or absence of auto-correlation is indicating through the Durbin Watson (DW) value. Based on the processed data results in this study, Durbin Watson (DW) reached 1.544 . This value has compared to the table value using a significance of 5\%, from a total sample of 97 (n) and the number of independent variables of $5(\mathrm{k}=5)$. The Durbin Watson table values have obtained from the above provisions, namely $\mathrm{dL}=1.5628$ and $\mathrm{dU}=1.7790$. Because the DW value (1.544) is less than the $\mathrm{k}-\mathrm{dU}$ value $(5-1.7790$ $=3.221$ ), it concludes that there is no auto-correlation. If the DW number is below -2, then there is positive autocorrelation. Meanwhile, if the DW number is between -2 to +2 , then there is no autocorrelation. However, it is different if the DW is above +2 , then it shows that it is autocorrelation.

The heteroscedasticity test has shown variants from the residuals of one observation to another in the regression model. A good regression model is homoscedasticity (a phenomenon in which the value of particular independent variables, each error has the same variant value). The heteroscedasticity is detected by seeking the presence or absence of specific patterns in the Scatterplot. Heteroscedasticity can be indicated if the dots form a regular pattern (wavy, widened, and narrowed). Conversely, heteroscedasticity does not occur if there is no consistent pattern; the dots spread above and below the zero on the Yaxis. From the processed data and the Scatterplot, heteroscedasticity does not occur (Fig.1). 


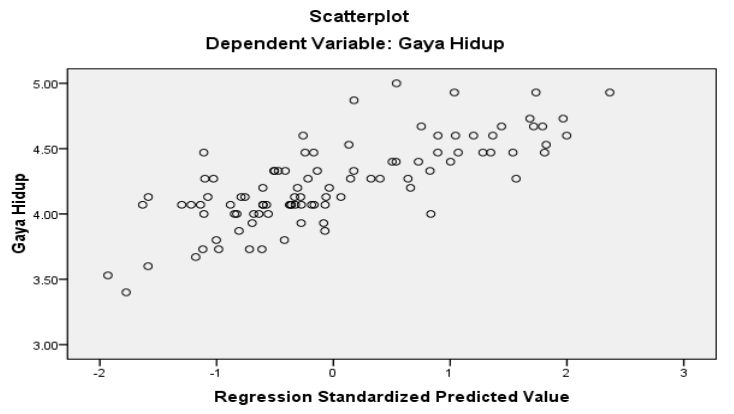

Fig. 1 The Scatterplot of Heteroscedasticity Test

The normality test has used to find whether the data has distributed normally. The normality of a variable and its residual value has detected through the graph method. The normality test has figured through the histogram and typical probability plot (Fig. 2).

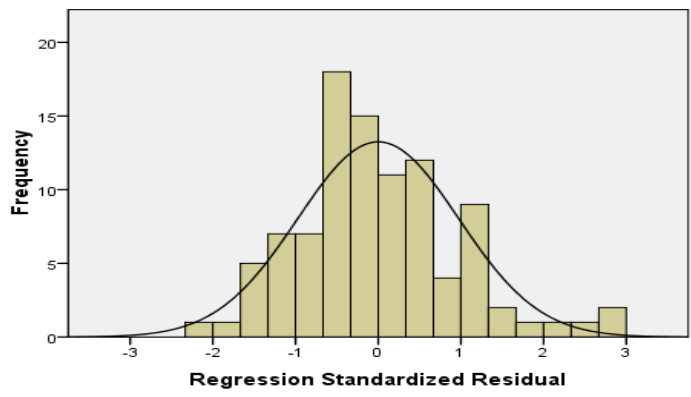

Mean $=5.80 \mathrm{E}-15$
Std. Dev $=0.974$
$N=97$

Fig. 2 The Histogram for Normality Test

The histogram in figure 2 shows that the data is in a curved bell-shaped line. The highest point on the curved line is parallel to the number zero. The numbers on the right-side of zero are equal to numbers on the left-side of zero. It means there is a balance. Then it finds that the research questionnaire data has distributed normally. The P-P Plot graph has figured that data distribution is around the diagonal line and follows the path (Fig. 3). Thus, the regression model in this study fits in the assumption of normality.

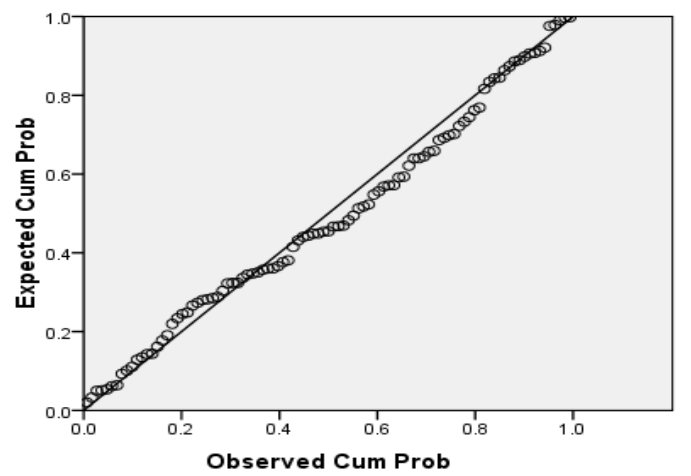

Fig. 3. The Normal P-P Plot of regression standardized residual

\section{The Multiple Regression Test}

The statistical method has used multiple regression analysis methods to examine the Living World Mall's effect on adolescents' lifestyle in Pekanbaru City. This test consists of 5 independent variables (convenience, comfort, diversity, entertainment, luxury, and the mall's essence and one dependent variable (teenage lifestyle). Through regression techniques, this can estimate the size of the independent variable parameters of the dependent variable. From testing multiple linear regression analysis, a constant number and regression coefficients are obtained (Table 3):

Table 3. The Multiple Regression Test

\begin{tabular}{|c|c|c|c|}
\hline \multirow[t]{2}{*}{ Model } & \multicolumn{2}{|c|}{$\begin{array}{l}\text { Unstandardized } \\
\text { Coefficients }\end{array}$} & \multirow{2}{*}{$\begin{array}{c}\text { Standardized } \\
\text { Coefficients } \\
\text { Beta }\end{array}$} \\
\hline & B & Std. Error & \\
\hline Constant & 1,405 & ,363 & \\
\hline Convenience &, 862 & , 106 & ,819 \\
\hline Comfort & , 157 & ,096 &, 175 \\
\hline Diversity & 238 &, 112 &, 282 \\
\hline Entertainment &,- 023 & ,097 &,- 021 \\
\hline Luxury \& Essence &, 017 & 055 &, 034 \\
\hline
\end{tabular}

Based on the data in table 3 , a multiple regression equation has arranged where the numbers listed in column B are the regression coefficients for the variables X1 to X5.

$\mathrm{Y}=\mathrm{B} 0+\mathrm{B} 1 \mathrm{X} 1+\mathrm{B} 2 \mathrm{X} 2+\mathrm{B} 3 \mathrm{X} 3+\mathrm{B} 4 \mathrm{X} 4+\mathrm{B} 5 \mathrm{X} 5+\varepsilon$

$\mathrm{Y}=1,405+0,862 \mathrm{X} 1+0,238 \mathrm{X} 2+0,017 \mathrm{X3}+0,157 \mathrm{X} 4-0,023 \times 5+\varepsilon$

The numbers in the regression equation shows:

1. $\mathrm{B} 0=1.405 \rightarrow$ It is the minimum value of lifestyle if the variables of convenience, comfort, diversity, entertainment, luxury and mall essence are assumed to be constant values (0);

2. $\mathrm{B} 1=0.862 \rightarrow$ If there is a change inconvenience by one unit with the assumption that comfort, diversity, entertainment, luxury and the essence of the mall have fixed, then the lifestyle will change by 0.862 units;

3. $\mathrm{B} 2=0.238 \rightarrow$ If there is a change in comfort by one unit with the assumption that convenience, diversity, entertainment, luxury and the essence of the mall have fixed, then the lifestyle will change by 0.238 units;

4. $\mathrm{B} 3=0.017 \rightarrow$ If there is a change in diversity by one unit assuming convenience, comfort, entertainment, luxury, and the essence of the mall has fixed, then lifestyle will also change by 0.017 unit;

5. $\mathrm{B} 4=0.157 \rightarrow$ If there is a change in entertainment by one unit with the assumption that the convenience, comfort, diversity, luxury and essence of the mall have fixed, then the lifestyle will change by 0.157 units;

6. $\mathrm{B} 5=0.023 \rightarrow$ If there is a change in the mall's luxury and essence by one unit assuming that convenience, comfort, diversity and entertainment are constant, the lifestyle changes by 0.023 units.

\section{The t-test (partial)}

The t-test (partial) has used to test the effect of each independent variable, namely convenience (X1), comfort 
(X2), diversity (X3), entertainment (X4), luxury and mall essence (X5) on the dependent variable (dependent) namely the youth lifestyle (Y). The t-table value has a stipulated degree of freedom of $\mathrm{n}-\mathrm{k}(97-5=92)$ and a confidence level of $95 \%$ ( $\mathrm{Sig}=0.05)$. In this test, the t table value has obtained by the result of t table $=1.66159$ at the percentage point of the $t$ distribution (df) 92 and Probability (Pr) 0.05 . The $t$ (partial) test has conducted by comparing the $t$ count with the t table in each variable $\mathrm{X}$. The $\mathrm{t}$ value has shown in table 4:

Table 4. The t-test (Partial)

\begin{tabular}{lrrrr}
\hline \multicolumn{1}{c}{ Model } & \multirow{2}{*}{ t Count } & \multirow{2}{*}{ Sig } & \multicolumn{2}{c}{ Correlation LifeStyle } \\
& & & Values & \% \\
\hline Constant & 5,873 &, 000 & 1,000 & \\
Convenience & 8,116 &, 000 &, 731 & 40,28 \\
Comfort & 3,130 &, 000 &, 477 & 26,28 \\
Diversity &, 299 &, 766 &, 174 & 9,59 \\
Entertainment & 2,669 &, 005 &, 377 & 20,77 \\
Constant &,- 233 &, 816 &, 056 & 3,09 \\
\hline
\end{tabular}

Based on the t-test data in table 4, the hypothesis on each independent variable (independent), whether the independent variable influences or not on adolescents' lifestyle. The percentage effect of each independent variable as follows:

a. Hypothesis X1 Test (Convenience)

Processed data in table 4 , it is known that the value of $t$ count in the convenience variable is greater than the value of $\mathrm{t}$ table, namely: $\mathrm{t}$ count $(8,116)>\mathrm{t}$ table (1.66159). In addition, the probability value in this aspect is 0,000 (Sig. $0,000<0.005$ ). This condition indicates that the hypothesis $\mathrm{H} 0$ has rejected and $\mathrm{H} 1$ has accepted; it means that the convenience variable has a significant effect on adolescent lifestyle. The magnitude of the influence of the convenience variable has taken from the percentage of Lifestyle Correlations. The table partially shows that the Living World Mall's convenience variable influences $40.28 \%$ of adolescents' lifestyle.

b. Hypothesis X2 Test (Comfort)

Based on the data in table 4, it has found that the value of $t$ arithmetic on the convenience variable is greater than the value of the $t$ table, namely: $t$ arithmetic (3.130)> $t$ table (1.66159). In addition, the probability value in this aspect is 0,000 ( $\mathrm{Sig}$. $0,000<0.005$ ). This condition indicates that the hypothesis $\mathrm{H} 0$ has rejected and $\mathrm{H} 2$ has accepted; it means that the comfort variable significantly influences adolescent lifestyle. The magnitude of the effect of comfort variables has figured from the percentage of Lifestyle Correlations. The table partially shows that Living World Mall's comfort variable affects $26.28 \%$ of teenagers' lifestyle.

c. Hypothesis X3 Test (Diversity)

From the data table 4, the $\mathrm{t}$ value of the diversity variable is smaller than the $t$ table value, namely: $t$ count $(0.299)$ $<t$ table (1.66159). In addition, the probability value in this aspect is 0.766 (Sig. 0.766> 0.005). Thus the hypothesis $\mathrm{H} 0$ is accepted, and $\mathrm{H} 3$ has rejected; it means that the diversity variable does not significantly affect adolescent lifestyle. The magnitude of the influence of the diversity variable has obtained from the percentage of Lifestyle Correlations. The table partially shows that the Living World Mall's diversity variable only affects $9.59 \%$ of adolescents' lifestyle.

d. Hypothesis Test X4 (Entertainment)

Based on data in table 4, the t value in the entertainment variable is higher than the $t$ table value, namely: $t$ count (2.669)> t table (1.66159). Besides, the probability value in this aspect is 0.005 (Sig. $0.005 \leq 0.005$ ). It shows that the hypothesis $\mathrm{H} 0$ has rejected and $\mathrm{H} 4$ has accepted; it means that the entertainment variable has a significant effect on adolescent lifestyle. The magnitude of the influence of the entertainment variable has seen from the percentage of Lifestyle Correlations. The table partially shows that the Living World Mall's entertainment variable affects $20.77 \%$ of teenagers' lifestyle.

e. Hypothesis X5 Test (Luxury and the Essence of a Mall) With the help of the SPSS device, the data in table 4 shows that the $t$ value of the luxury and mall essence variables is smaller than the table value, namely: $t$ count $(0.233)<t$ table (1.66159). In addition, the probability value in this aspect is 0.816 ( $\mathrm{Sig}$. 0.816>0.005). It shows that the hypothesis $\mathrm{H} 0$ is accepted and $\mathrm{H} 5$ has rejected, which means that the variables of luxury and the mall's essence do not significantly affect adolescent lifestyle. The magnitude of the luxury variable's influence and the mall's essence has found from the percentage of Lifestyle Correlations. The table partially shows that the variables of luxury and the Living World Mall's essence only affect $3.09 \%$ of teenagers' lifestyle.

\section{The F Test (Simultaneous)}

Analysis of variance (ANOVA) has used to determine whether the independent variables (convenience, comfort, diversity, entertainment, luxury and the essence of the mall) simultaneously have a significant effect on the dependent variable (lifestyle). ANOVA tests the relationship between one dependent variable and one or more independent variables to find the calculated $F$ value. The independent variable in this study is a manifestation of Mal Living World's influence on adolescent lifestyles. The impact of the Living World Mall on the young lifestyle has figured in the hypothesis below:

Ho: There is no influence of The Living World Mall on the lifestyle of teenagers in Pekanbaru City

Ha: The Living World Mall influences the lifestyle of teenagers in Pekanbaru City

Table 5. The F Test (Simultaneous) - Anova

\begin{tabular}{lrrrrr}
\hline Model & $\begin{array}{r}\text { Sum of } \\
\text { Squares }\end{array}$ & df & $\begin{array}{c}\text { Mean } \\
\text { Square }\end{array}$ & F & Sig. \\
\hline Regression & 5,860 & 5 & 1,172 & 25,081 & $.000^{\text {a }}$ \\
Residual & 4,252 & 91 &, 047 & & \\
Total & 10,113 & 96 & & & \\
\hline
\end{tabular}


Table 5 is the result of the $\mathrm{F}$ test through ANOVA. It has known that the value of $\mathrm{F}$ count $=25.081$. To find out the $\mathrm{F}$ table value, $\mathrm{n}$ (number of samples) $=97$ and $\mathrm{k}$ (number of independent variables) $=5$. From these provisions, the $\mathrm{df}$ value for the denominator $(\mathrm{N} 2)=\mathrm{n}-\mathrm{k}-1=97-5-1=91$, while the df value for the numerator $(\mathrm{N} 1)=\mathrm{k}=5$. Thus, it determines that the value of $\mathrm{F}$ table $=2.31$.

Based on the $\mathrm{F}$ value data, it is known that the calculated $F$ value (25.081)> the $F$ table value (2.31). In addition, the simultaneous influence probability value is 0,000 (Sig. $0,000<0.005$ ). This analysis shows that the hypothesis $\mathrm{H} 0$ has rejected and $\mathrm{Ha}$ has accepted. It means that the Living World Mall's influence on teenagers' lifestyle in Pekanbaru city where the independent variables (convenience, comfort, diversity, entertainment, luxury and the essence of the mall) together (simultaneously) have a significant effect on the lifestyle of adolescents.

\section{Coefficient of Determination (R2)}

The determination coefficient test has conducted to determine the proportion or percentage of all independent variables $(\mathrm{X})$ on the dependent variable $(\mathrm{Y})$. This influence is known as correlation $(\mathrm{R})$. The remaining ratio $(100-\mathrm{R})$ influences other variables that have excluded from the research model. The test values for the coefficient of determination have presented in table 6 .

Table 6. The Determination Coefficient Test (Model Summary)

\begin{tabular}{lrrrr} 
Model & R & R Square & $\begin{array}{l}\text { Adjusted } \\
\text { R Square }\end{array}$ & $\begin{array}{l}\text { Std. Error of } \\
\text { the Estimate }\end{array}$ \\
\hline 1 & $.761^{\mathrm{a}}$ &, 579 &, 556 &, 21617 \\
\hline
\end{tabular}

Based on table 6 shows that the SPSS results provide several alternatives to the correlation value. The first alternative is the value of $\mathrm{R}$. This value is usually more significant than the value of the next option. However, R can be contaminated by other amounts that cause measurement errors (inaccurate). The second alternative is the $\mathrm{R}$ Square Value, which is the adjusted $\mathrm{R}$-value. This value is more accurate than the R-value (moderate accuracy). The third alternative is the Adjusted $\mathrm{R}$ Square value, which is the adjusted R Square value (high level of accuracy). Therefore, to get an accurate effect value, this study uses the Adjusted R Square value. From table 5, it knows that the Adjusted R Square value is 0.556 . This value shows the influence of the Living World Mall on adolescent lifestyles by $55.6 \%$. Meanwhile, $44.4 \%$ is the influence of other factors not examined in this study.

\section{CONCLUSION}

In this research, a shopping mall becomes a medium and giving influence to young lifestyles. The characteristics of adolescents' visitors to the Living World Mall in
Pekanbaru City are mostly women aged 20-24 years with a college education. They are mostly visiting on weekends with an average of 5-6 times/month. The visiting time is about 3-4 hours, except for younger women aged 15-19 and boys aged 20-24 years who spent 2-3 hours. For young women aged 11-14, 20-24 and young men aged 15-19 years, they visit the mall at 4.00-6.00 PM. Meanwhile, women aged 15-19 and boys aged 11-14, 20-24 years came to the mall at 1.00-4.00 PM. On average, adolescents go to the mall with friends/relatives. An exception for women aged 20-24 who visit with their partners.

Younger women aged 11-14, 20-24 years old go to malls to eat/drink, while other age groups go to malls to hang out, play games, and watch movies. The most significant expenditure for adolescent girls aged 11-14, 1519 and boys aged 20-24 years is for consumption costs. Meanwhile, for other age groups, the most significant expense is to watch movies in theatres.

Girls are aged 11-14, 15-19 and boys aged 11-14 are attracted to malls due to the sale programs. In contrast, young women aged 20-24 and young men aged 15-19 years are interested in coming to the mall because of the comfortable and safe atmosphere. Meanwhile, men aged 2024 years are attracted to the mall because the goods served are different from other malls.

These adolescents' characteristics illustrate that the male respondents, on average, have features with activities that lead to pleasure and a desire to live comfortably, instantaneously, and less complicated. This can be seen from their activities, such as hanging out, watching movies, eating fast food, etc. The respondents also have an interest in something that is considered essential and different from the surrounding environment.

The Living World Mall's magnitude in Pekanbaru City influence on adolescent lifestyle shows that the hypothesis $\mathrm{Ha}, \mathrm{H} 1, \mathrm{H} 2$, and $\mathrm{H} 4$ are accepted. It means that there is a significant influence on lifestyle. While hypothesis $\mathrm{H} 3, \mathrm{H} 5$ is rejected, it implies that there is no significant influence on lifestyle. According to the Adjusted R Square value, the mall affects adolescents' lifestyle in Pekanbaru City by $55.60 \%$.

In comparison, the remaining $44.4 \%$ has influenced by other factors not examined in this study. For the amount of influence partially, the convenience variable (X1) has an impact on the lifestyle of $40.28 \%$; comfort variable (X2) has an effect of $26.28 \%$; diversity variable (X3) has an effect of $9,59 \%$; entertainment variable (X4) has an effect of $20.77 \%$, and the variable of luxury and mall essence (X5) has an effect of $3.09 \%$. From the size of the influence of the variables partially, it has known that the convenience variable is the variable that has the most significant impact on adolescent lifestyle.

\section{REFERENCES}

[1] Chizuwa. Jun, Perubahan Gaya Hidup Anak Muda di Surakarta Akibat Berkembangnya Mal. Tesis. Universitas Sebelas Maret Surakarta, 2014. 
[2] Quigley. Sandra Rianna, Pengaruh Interior Mall Terhadap Kehidupan Sosial, Gaya Hidup dan Penampilan Remaja. Jurnal. Institut Teknologi Bandung, 2017.

[3] Kabalmay. Yudi AD, Café Addict: Gaya Hidup Remaja Perkotaan. Jurnal. Universitas Airlangga, 2016.

[4] Ibrahim. Idi Subandy, Ecstasy Gaya Hidup: Kebudayaan Pop dalam Masyarakat Komuditas Indonesia. Mizan, Bandung, 1997.

[5] Ismail. M. El-Adly, Shopping Mall Attractiveness: A segmentation approach. United Arab Emirates University, Uni Emirat Arab.

[6] Iskandar. Vincent, Studi kinerja shopping center ditinjau dari perbandinga tingkat kepentingan terhadap kepuasan pengunjung dan penyewa. Magister Teknik Perencanaan, Universitas Tarumanegara, Jakarta, 2017.

[7] Sugiono, Metodologi Penelitian Kuantitatif, Kualitatif, dan $R \& D$. Alfabeta. Bandung, 2018.

[8] Sevilla. Consuelo G, Research Methods. Rex Printing Company. Quezon City, 2007.

[9] Wibisono. Dermawan, Riset Bisnis: Panduan Bagi Praktisi dan Akademis. PT. Gramedia Pustaka Utama. Jakarta, 2003.

[10] Priyatno, Mandiri Belajar SPSS. Yogyakarta. MediaKom, 2008.

[11] Sugiyono, Metodologi Penelitain Kuantitatif. Edisi kedua, 2008.

[12] Sumarwan. Ujang, Perilaku Konsumen Teori dan Penerapannya dalam Pemasaran. Ghalia Indonesia, Bogor, 2011. 